\title{
The Influence of Tillage and Irrigation on the Maize Production
}

\author{
Violeta SIMIONESCU ${ }^{1,2^{*}}$ Monica TANC ${ }^{2,}$, Marioara RUSU ${ }^{3}$, Daniela PLESOIANU ${ }^{1}$ \\ ${ }^{1}$ Ovidius University,124 Mamaia Blvd, 900527, Constanta, Romania, \\ ${ }^{2}$ SCDA Valu lui Traian, Calea Dobrogei Str, 460, 907300, Valu lui Traian, Constanta \\ ${ }^{3}$ Institute of Agricultural Economics, Romanian Academy, 13, Calea 13 Septembrie, District 5, \\ Bucharest, Romania, Phone: +400213182411 \\ *corresponding author, e-mail: violetams59@yahoo.com
}

Bulletin UASVM series Agriculture 73(1)/2016

Print ISSN 1843-5246; Electronic ISSN 1843-5386

DOI 10.15835/buasvmcn-agr: 12018

\begin{abstract}
The main objective of this project is to elaborate a non-conventional tillage system for various agro-pedoclimatic areas of Romania, characterized by the reduction of drought effects and production stability, the reduction of technological inputs and increase of economic efficiency, the efficient capitalization of limited water resources, soil preservation and environmental protection. By comparison with the traditional tillage system for maize, namely plowing, the experiment is statistically backed, with the significance very significantly negative. If we relate to the vibromix tillage, the productions are statistically backed and are very significant in the version cultivated in conditions of $100 \%$ irrigation and 50\% irrigation. The research has been carried out at the Valul lui Traian Station for Agricultutral Research and Development. The experiments were placed according to the method of subdivided plots, in three repetitions on the field, with tillage systems adapted to the local conditions and consisted of the following versions: the level of water supply (three graduations), deep loosening of the soil (two graduations), basic tillage (three graduations). Maize reacted very well to tillage. Taking into account the high cost of irrigation in Dobrudja, these results support the farmers by offering solutions for the need to reduce production costs without diminishing production.

The analysis of the yield obtained in maize as an effect of tillage shows that the chisel plow works are statistically very significant. Maize reacts well to vibromix tillage when the field is chisel plowed or not and/or irrigated-not irrigated, resulting in productions that are quantitatively close to those obtained by plowing, but with a capitalization rate higher than in this version.

The research results showed us that a chisel plow work done every three or four years and irrigation with only $50 \%$ of the AHI can result in productions close the ones obtained by irrigation with $100 \%$ of the AHI.
\end{abstract}

Keywords: irrigation, maize, production, tillage

\section{INTRODUCTION}

The promotion of conservation agriculture system in versions adapted to the soil conditions with mid-heavy texture (30-42\% clay in the arable horizon) and to the requirements of the main crops in the south of Romania which should provide competitive productions, both quantitatively and qualitatively, with reduced costs and high profit, taking into account soil improvement and environmental protection (Cociu A. and Cismas G.D. , 2011)..

The elaboration of a nonconventional soil tillage system adapted to various agro-pedoclimatic areas of Romania targets the following:

- the possibility to use soil loosening methods without overturning the furrow, by working with the chisel or paraplow, with superior 
economic results, especially in cereals, and important beneficial effects on the evolution of soils;

- reduced soil tillage, including any system where modifications of the conventional technology are applied, with the purpose of reducing the degree of soil mobilization, the number of crossings over the field and of expenses;

- sowing on untilled field;

- to restore the soil content in organic matter by incorporating vegetal remains and by the cultivation by rotation of plants that restore soil fertility;

- preservation of soil water by protecting the soil with various types of mulch, preventing thus water loss by evaporation at ground level.

To obtain more information and recommendations regarding the stability of high production that is also economically efficient, in the major crops, in normal or critical natural conditions, based on the integrated and highly efficient use of natural resources and inputs, in compliance with the EU norms of soil conservation and environmental protection.

\section{MATERIALS AND METHODS}

The soil in the location perimeter of the experimental lot is vermic chernozem, formed on loess deposits, with medium texture, namely loamy to loamy-earthen, with a clay content between 28 and $32 \%$, distributed homogenously in the soil profile. The soil is light and very light (the degree of subsidence being under 0\%), emphasizing a high risk for degradation by excessive loosening on short-term and a high risk for secondary depth compaction on long-term. The soil permeability to water is high (the numeric values of the hydraulic conductivity being over $20-30 \mathrm{~mm} \cdot \mathrm{h}^{-1}$ ). In the area, groundwater is usually deeper than $10 \mathrm{~m}$. Consequently, the natural drainage is good and the risk of excess humidity (at the surface or at depth) is highly reduced.

The structural hydrostability of the soil is reduced, the content of water-stable structural macroaggregates is under 4-8\%, emphasizing thus a high risk of soil degradation by destructuration, especially in the intensely irrigated areas, and particularly at the surface.

The soil supply with nutritive elements is moderate. Thus, in the first 10 and $20 \mathrm{~cm}$, respectively, the humus content was between 3.59 and $3.02 \%$; the content of mobile phosphorus was between 60 and $40 \mathrm{mg} \cdot \mathrm{kg}^{-1}$, total nitrogen was between 0.23 and $0.20 \%$, and potassium was between 180 and 170 mg.kg .

The soil reaction was poor to moderately alkaline, the $\mathrm{pH}$ (determined in water) being 8.008.02.

At the same time, the project has important positive economical effects resulted from the larger surfaced tilled at one crossing. By the basic work of the soil with the chisel, the average fuel consumption is reduced by $40-50 \%$ per ha, the work time is reduced by approx. 8-\% per ha, and the expenses with spare parts, maintenance and amortization of technical equipment by approx. $20-40 \%$.

The experiments were placed according to the method of subdivided plots, in three repetitions on the field, with tillage systems adapted to the local conditions, oriented towards the protection of the agrophysical state of the soil, towards water conservation and economical optimization of the agricultural management and consisted of the following versions:

\section{A. The level of water supply}

A1 - full-time irrigation $(1 \mathrm{~m})$ on $0-90 \mathrm{~cm}$;

A2 - half-time irrigation $(1 / 2 \mathrm{~m})$ on $0-90 \mathrm{~cm}$;

A3 - not irrigated.

\section{B. Deep loosening of the soil}

B1 - by chisel plow (work executed at the beginning of the experiments);

B2 - no chisel plow work.

\section{Basic tillage}

C1 - plowing with moldboard plow $20-22 \mathrm{~cm}$;

C2 - plowing with chisel plow $18-20 \mathrm{~cm}$;

C3 - tillage with disk plow $13-15 \mathrm{~cm}$;

The plants cultivated every year by rotation were: maize, soy and wheat.

Fertilization and other specific works for plant protection during the vegetation period, and pest and disease control were applied uniformly for all versions.

In the irrigated plots, one to three waterings were applied uniformly, according to the plant requirements, but also to the technical and economical possibilities.

Observations were accomplished of the evolution of the vegetative phenophases.

The average yield per ha was determined and the productivity elements were analyzed. 
Soil samples were collected in order to establish soil humidity.

Also, soil samples were collected in order to establish the effect of tillage on certain physical and chemical soil indicators.

\section{RESULTS AND DISCUSSION}

The purpose of tillage is to create the best conditions for the sowing and germination of seeds, as well as for the springing, growth and development of plants. By comparison with the traditional tillage system for maize, namely plowing, the experiment is statistically backed, with the significance very significantly negative. However, the productions are very high (Tab.1).

Maize reacted very well to tillage (Tab. 1). In the experimental versions, high productions on average were obtain for three years and they were between $8231 \mathrm{~kg} / \mathrm{ha}$ in the irrigated 50\%/no chisel plow/chisel work version and $12432 \mathrm{~kg} / \mathrm{ha}$ in the irrigated/chisel plow/plowing version, the latter also representing the maximum production per experiment.
With $50 \%$ of the active humidity interval (AHI) we can obtain productions similar to the ones obtained in the version without chisel plow and irrigated with norms of $100 \%$ of the AHI (Tab.1).

If we relate to the vibromix tillage, the productions are statistically backed and are very significant in the version cultivated in conditions of $100 \%$ irrigation and $50 \%$ irrigation/ plowing(Tab.2)

In the versions with irrigation $100 \%$ and chisel plow work, the productions were over $11000 \mathrm{~kg} / \mathrm{ha}$ in all the three types of tillage, while in the plowed version, the production was 12432 $\mathrm{kg} / \mathrm{ha}$.

In the versions with irrigation $100 \% /$ no chisel plow work and irrigation 50\%/chisel plow work, the productions were over $10000 \mathrm{~kg} /$ ha. This leads to the conclusion that with chisel plow work, done once every three or four years, and irrigation with only $50 \%$ of the $\mathrm{AHI}$, we can obtain productions close to those accomplished by irrigation with $100 \%$ of the AHI. Taking into account the high cost of irrigation in Dobrudja, these results support the farmers by offering

Tab. 1. The maize production obtained as an effect of tillage and various water supply regimen,Valul lui Traian, 2008-2010

\begin{tabular}{|c|c|c|c|c|c|c|c|c|c|}
\hline \multirow{3}{*}{$\frac{N R}{1}$} & \multicolumn{3}{|c|}{ VARIANTA } & \multicolumn{2}{|c|}{ PRODUCTIA } & \multirow{2}{*}{\multicolumn{2}{|c|}{$\begin{array}{c}\text { DIFERENTA } \\
\text { KG/HA }\end{array}$}} & \multirow{2}{*}{\multicolumn{2}{|c|}{ SEMNF. }} \\
\hline & \multirow{2}{*}{$\begin{array}{l}\text { Irigat } \\
100 \%\end{array}$} & \multirow{2}{*}{$\frac{\text { Scarif./Nscr. }}{\text { Scarif. }}$} & \multirow{2}{*}{$\frac{\text { Lucr.sol }}{\mathrm{A}}$} & \multirow{2}{*}{$\begin{array}{l}\mathrm{Kg} / \mathrm{ha} \\
12432\end{array}$} & \multirow{2}{*}{$\frac{\%}{100}$} & & & & \\
\hline & & & & & & Mt. & 3720 & Mt. & $* * *$ \\
\hline 2 & $100 \%$ & Scarif. & $\mathrm{C}$ & 11093 & 89 & -1339 & 2381 & 000 & $* * *$ \\
\hline 3 & $100 \%$ & Scarif. & VB & 11625 & 93 & -807 & 2913 & 000 & $* * *$ \\
\hline 4 & $100 \%$ & Nescarf. & A & 11215 & 90 & -1217 & 2503 & 000 & $* * *$ \\
\hline 5 & $100 \%$ & Nescarf. & C & 10324 & 83 & -2108 & 1612 & 000 & $* * *$ \\
\hline 6 & $100 \%$ & Nescarf. & VB & 10725 & 86 & -1707 & 2013 & 000 & $* * *$ \\
\hline 7 & $50 \%$ & Scarif. & $\mathrm{A}$ & 10953 & 88 & -1479 & 2241 & 000 & $* * *$ \\
\hline 8 & $50 \%$ & Scarif. & C & 10246 & 82 & -2186 & 1534 & 000 & $* * *$ \\
\hline 9 & $50 \%$ & Scarif. & VB & 10875 & 87 & -1557 & 2163 & 000 & $* * *$ \\
\hline 10 & $50 \%$ & Nescarf. & $\mathrm{A}$ & 9073 & 72 & -3359 & 361 & 000 & \\
\hline 11 & $50 \%$ & Nescarf. & $\mathrm{C}$ & 8231 & 66 & -4201 & -481 & 000 & \\
\hline 12 & $50 \%$ & Nescarf. & VB & 9654 & 77 & -2778 & 942 & 000 & \\
\hline 13 & $0 \%$ & Scarif. & $\mathrm{A}$ & 10700 & 86 & -1732 & 1988 & 000 & $* * *$ \\
\hline 14 & $0 \%$ & Scarif. & $\mathrm{C}$ & 10233 & 82 & -2199 & 1521 & 000 & $* * *$ \\
\hline 15 & $0 \%$ & Scarif. & VB & 9741 & 78 & -2691 & 1029 & 000 & $* * *$ \\
\hline 16 & $0 \%$ & Nescarf. & $\mathrm{A}$ & 8712 & 70 & -3720 & Mt & 000 & \\
\hline 17 & $0 \%$ & Nescarf. & $\mathrm{C}$ & 9462 & 76 & -2970 & 750 & 000 & \\
\hline 18 & $0 \%$ & Nescarf. & VB & 9301 & 74 & -3131 & 589 & 000 & \\
\hline
\end{tabular}


solutions for the need to reduce production costs without diminishing production.

Tillage accomplished on a field with irrigation $50 \% /$ no chisel plow work provided large productions, somewhere between $8231 \mathrm{~kg} / \mathrm{ha}$ in the chisel version and $9654 \mathrm{~kg} / \mathrm{ha}$ in the vibromix version. It is important to observe the latter version, where the production was $581 \mathrm{~kg}$ higher than the plowed version.

In conditions of no irrigation and chisel plow work at the beginning of the experiment, the highest production was in the plowed version, namely $10700 \mathrm{~kg} / \mathrm{ha}$. In the maize sown after chisel plow and chisel work, the production was $10233 \mathrm{~kg} / \mathrm{ha}, 467 \mathrm{~kg} / \mathrm{ha}$ less than in the indicated version.

The analysis of the yield obtained in maize as an effect of tillage (Tab.3) shows that the chisel plow works are statistically very significant, with $11361 \mathrm{~kg} / \mathrm{ha}$ in the plowed version, $10747 \mathrm{~kg} / \mathrm{ha}$ in the vibromix version, and $10524 \mathrm{~kg} / \mathrm{ha}$ in the chisel version (Tab.3). It is interesting and worth remembering that when the chisel plow was not used, the highest production was in the vibromix version, $9893 \mathrm{~kg} / \mathrm{ha}$.

In regards to the maize reaction to tillage and irrigation, it can be observed in Tab. 4 that the production is between $11823 \mathrm{~kg} / \mathrm{ha}$ (irrigated 100\%/plowing) and $9238 \mathrm{~kg} / \mathrm{ha}$ (irrigated 50\%/ chisel). We also observe a very good form for maize in the vibromix/irrigated $100 \%$ and irrigated 50\% versions, the production being $11175 \mathrm{~kg} / \mathrm{ha}$ and $10264 \mathrm{~kg} / \mathrm{ha}$, respectively, 467kg/ha and 1026 $\mathrm{kg} / \mathrm{ha}$ more, compared to the chisel version.

\section{CONCLUSION}

The analysis of the results obtained leads to the following conclusions:

Maize reacts well to vibromix tillage when the field is chisel plowed or not and/or irrigated-

Tab. 2. Maize production under the influence of tillage and of various water supply levels, Valul lui Traian, 2008-2010

\begin{tabular}{|c|c|c|c|c|c|c|}
\hline \multirow{2}{*}{ NR } & \multicolumn{2}{|c|}{ Varianta } & \multicolumn{2}{|c|}{ Productia } & \multirow{2}{*}{$\frac{\text { dif. }}{\mathrm{Kg} / \mathrm{ha}}$} & \multirow{2}{*}{$\begin{array}{l}\text { Semni- } \\
\text { ficatia }\end{array}$} \\
\hline & Irigat & Lucr.sol & $\mathrm{Kg} / \mathrm{ha}$ & $\%$ & & \\
\hline 1 & $100 \%$ & $\mathrm{~A}$ & 11823 & 100 & $\mathrm{Mt}$ & \\
\hline 2 & $100 \%$ & $\mathrm{C}$ & 10708 & 90 & -1115 & 000 \\
\hline 3 & $100 \%$ & VB & 11175 & 94 & -648 & 000 \\
\hline 4 & $50 \%$ & A & 10013 & 100 & Mt & \\
\hline 5 & $50 \%$ & $\mathrm{C}$ & 9238 & 92 & -775 & 000 \\
\hline 6 & $50 \%$ & VB & 10264 & 102 & +251 & $* * *$ \\
\hline 7 & $0 \%$ & A & 9706 & 100 & $\mathrm{Mt}$ & \\
\hline 8 & $0 \%$ & $\mathrm{C}$ & 9847 & 101 & +141 & $* * *$ \\
\hline 9 & $0 \%$ & VB & 9521 & 98 & -185 & 000 \\
\hline
\end{tabular}

Tab. 3. Maize production under the influence of tillage and chisel plow work permanence, Valul lui Traian, 2008-2010

\begin{tabular}{|c|c|c|c|c|c|c|}
\hline \multirow{2}{*}{$\mathrm{Nr}$} & \multirow{2}{*}{$\begin{array}{c}\text { Varianta } \\
\text { Scarif./Nscr. }\end{array}$} & \multicolumn{2}{|c|}{ Productia } & \multicolumn{2}{|c|}{ Diferenta } & \multirow{2}{*}{ Semnif. } \\
\hline & & Lucr.sol & $\mathrm{Kg} / \mathrm{ha}$ & $\%$ & $\mathrm{Kg} / \mathrm{ha}$ & \\
\hline 1 & Scarif. & $\mathrm{A}$ & 11361 & 117 & 1700 & $* * *$ \\
\hline 2 & Scarif. & $\mathrm{C}$ & 10524 & 108 & 863 & $* * *$ \\
\hline 3 & Scarif. & VB & 10747 & 111 & 1086 & $* * *$ \\
\hline 4 & Nescarf. & $\mathrm{A}$ & 9661 & 100 & $\mathrm{Mt}$ & \\
\hline 5 & Nescarf. & $\mathrm{C}$ & 9339 & 96 & -322 & 000 \\
\hline 6 & Nescarf. & VB & 9893 & 102 & 232 & $* * *$ \\
\hline
\end{tabular}


not irrigated, resulting in productions that are quantitatively close to those obtained by plowing, but with a capitalization rate higher than in this version.

In conditions of water supply at $50 \%$ of the AHI and no irrigation, with or without chisel plow work, the profit is similar in all tillage versions, so we can recommend the other two tillage systems as alternative to plowing in order to protect the physical parameters of the soil.

The research results showed us that a chisel plow work done every three or four years and irrigation with only $50 \%$ of the AHI can result in productions close the ones obtained by irrigation with $100 \%$ of the AHI.

Given the high costs of irrigation in Dobrudja, these results support the farmers by offering solutions to the need to reduce production costs without diminishing the production.
It was remarked from the analysis of the results that if the chisel plow is not used, the highest yield was obtained in the vibromix version, namely $9893 \mathrm{~kg} / \mathrm{ha}, 232 \mathrm{~kg} / \mathrm{ha}$ more compared to the plowed version and $554 \mathrm{~kg} /$ ha more compared to the chisel version.

We must emphasize the fact that by tillage at water consumption reduced at half compared to the versions irrigated with $100 \%$ of the AHI (between $363.8 \mathrm{~mm} / \mathrm{ha} /$ year and $366.8 \mathrm{~mm} /$ ha/year), after irrigation $50 \%$ and chisel plow work, the following productions were obtained: 10953 in the plowed version, $10875 \mathrm{~kg} / \mathrm{ha}$ in the vibromix version and $10246 \mathrm{~kg} / \mathrm{ha}$ in the chisel version, which recommends these versions before those with water supply at $100 \%$ of the AHI.

\section{REFERENCES}

1. Cociu A Cismas GD (2011). Influence of different tillage systems on grain maize yield and on soil properties, I.N.C.D.A. Fundulea Annals, Vol. LXXIX, nr. L. 